\title{
Techniques for the Study of Adult Stem Cells: Be Fruitful and Multiply
}

\author{
Carlos A. Ramos, Teresa A. Venezia, Fernando A. Camargo, and Margaret A. Goodell \\ Baylor College of Medicine, Houston, TX, USA
}

BioTechniques 34:572-591 (March 2003)

\section{INTRODUCTION}

Initially proposed by Pappenheim in 1917 (1), the notion that stem cells are responsible for the renewal of the hematopoietic system was corroborated by several groups during the $1950 \mathrm{~s}$ and 60s (2-5). This idea that adult tissue regeneration depends on a small population of resident cells has been more recently extended to other tissues such as epithelia, muscle, and the nervous system (6). Understanding the physiology of these cells has become one of the most exciting endeavors of biology today.

Despite being conceptually simple, the definition of a stem cell is operationally challenging. A stem cell is defined as one that has the ability to selfrenew and the potential to give rise to several differentiated cell types; thus, to prove that a cell is indeed a stem cell, those two properties must be demonstrated. On the one hand, there is the need to observe the differentiation of the candidate cells; however, in doing so, they no longer are stem cells. On the other hand, there is the requirement that some of their progeny retain their original stem cell properties. Most of the experimental manipulations used to demonstrate potential to differentiate affect stem cells, changing their native properties. Furthermore, the exponential expansion of the differentiated progeny obscures the detection of the original stem cell population.

Another hurdle that stem cell biolo- gists have faced is the absence of a specific (i.e., present exclusively in stem cells) set of physical or chemical attributes. Several combinations of properties have been proposed and tested. However, at best, these allow the isolation of a subset of cells that is not truly a population of stem cells but a population that contains stem cells and that can be more or less enriched for stem cell activity. Needless to say, uncovering the exact phenotype of stem cells is one of the long-sought goals of stem cell biologists.

The generally accepted model of stem cell physiology (Figure 1) considers the existence of a unique grandparent stem cell that gives rise to all the possible progeny, but there is little understanding about what happens in between. The model assumes that the abilities to divide and differentiate are the opposites of a spectrum; that is, the more differentiated a cell is, the less potential it has to divide. This is an attractive, simple, partially supported hypothesis, but there are exceptions to this rule, such as when fully differentiated cells divide to replace dead cells (e.g., in the liver). Another assumption this model makes is that there are cellular states between stem cells and fully differentiated cells that are variably called transit, transit amplifying, or progenitor cells and that every time a cell climbs down the differentiation tree, there is a fate decision involved. However, several matters remain unsettled. We do not know whether there is always a unique stem cell or several stem cells with (possibly) similar phenotype. If the latter is the case, then this could explain why populations of stem cells that are isolated using different strategies can display similar behavior, despite being phenotypically distinct. Furthermore, the properties of transit cells are also unknown. If commitment is reversible, then, as already mentioned, phenotypically distinct cells (because of differentiation) can end up having the same potential; if there are different types of transit cells, then some that behave as stem cells in one assay system may not perform well in another. Finally, the way commitment or fate is determined is still a mystery: is it a stochastic process, a consequence of intrinsic cell asymmetry, or an effect of the environment in which the cells dwell? In principle, given the right conditions (especially if the culture time is long enough), any developmental pathway could potentially be activated and give rise to any particular type of cell. Having all these issues in mind makes it possible to understand the limitations of most studies.

In this work, we will review many of the techniques that are used to study adult stem cells, focusing on the hematopoietic stem cell (HSC) as a paradigm. We will begin by describing methods used to identify stem cells, including procedures used for their isolation, assays to study differentiation, and ways to assess self-renewal ability. The remainder of the article will deal with 
Table 1. Isolation Strategies for HSCs and Enrichment for Hematopoietic Activity Compared to Unfractionated Bone Marrow

\begin{tabular}{|c|c|c|c|}
\hline Purification Strategy & $\begin{array}{l}\text { Fold Enrichment in Multipotent } \\
\text { Hematopoietic Activity (Assay } \\
\text { Used for Calculation) }\end{array}$ & Fraction of WBM (\%) & Reference \\
\hline \multicolumn{4}{|l|}{ Sedimentation } \\
\hline Low density $\left(1.060-1.068 \mathrm{~g} / \mathrm{cm}^{3}\right)$ & 5 (LTR) & 14 & (28) \\
\hline \multicolumn{4}{|l|}{ Hoechst 33342} \\
\hline Holow & 12 (CFU-S day 12) & 6 & (15) \\
\hline FSChigh SSCintermediate Holow & 170 (CFU-S day 13 ) & 0.23 & (14) \\
\hline SP & 1000 (LTR) & 0.05 & (16) \\
\hline \multicolumn{4}{|l|}{ Rhodamine 123} \\
\hline Rholow low density & 21 (LTR) & 1 & (28) \\
\hline \multicolumn{4}{|l|}{ WGA } \\
\hline FSChigh SSChigh WGA high & 158 (CFU-S day 12$)$ & Not reported & (8) \\
\hline \multicolumn{4}{|l|}{ Monoclonal antibodies } \\
\hline Thy-1pos (rat) & 150 (CFU-S day 10$)$ & 5 & (78) \\
\hline Linneg & 15 (CFU-S 12) & 10 & (79) \\
\hline Thy-1.1 lowa Linneg/low Sca-1pos & 1000 (CFU-S) & 0.07 & (80) \\
\hline c-Kitpos Linneg/low Sca-1pos (KLS) & $500($ LTR $)$ & 0.1 & (81) \\
\hline c-Kitpos Thy-1.1 low Linneg/low Sca-1pos (KTLS) & 1000 (LTR) & 0.05 & (82) \\
\hline c-Kitpos Linneg/low Sca-1pos CD34neg/low & $\begin{array}{l}\text { Likely to be greater than } 1000 \\
\text { (single cell transplant) }\end{array}$ & 0.008 & (83) \\
\hline \multicolumn{4}{|c|}{$\begin{array}{l}\text { This table provides a rough estimate of the degree of enrichment attained by each of the purification strategies listed; the ex- } \\
\text { perimental conditions are variable and the different assays listed are not directly comparable. Some of the experiments in- } \\
\text { volved the preselection of cells (e.g., with sedimentation methods) before sorting for the phenotypes listed. All data refer to } \\
\text { mouse, except where noted. Note that the table numbers are approximate. WBM, whole bone marrow; LTR, long-term repop- } \\
\text { ulation; FSC, forward light scatter; SSC, side light scatter; Lin, lineage antibody cocktail. } \\
\text { aContrary to rat, the stem cell activity in mice resides in the bone marrow fraction that has a low expression level of Thy-1. }\end{array}$} \\
\hline
\end{tabular}

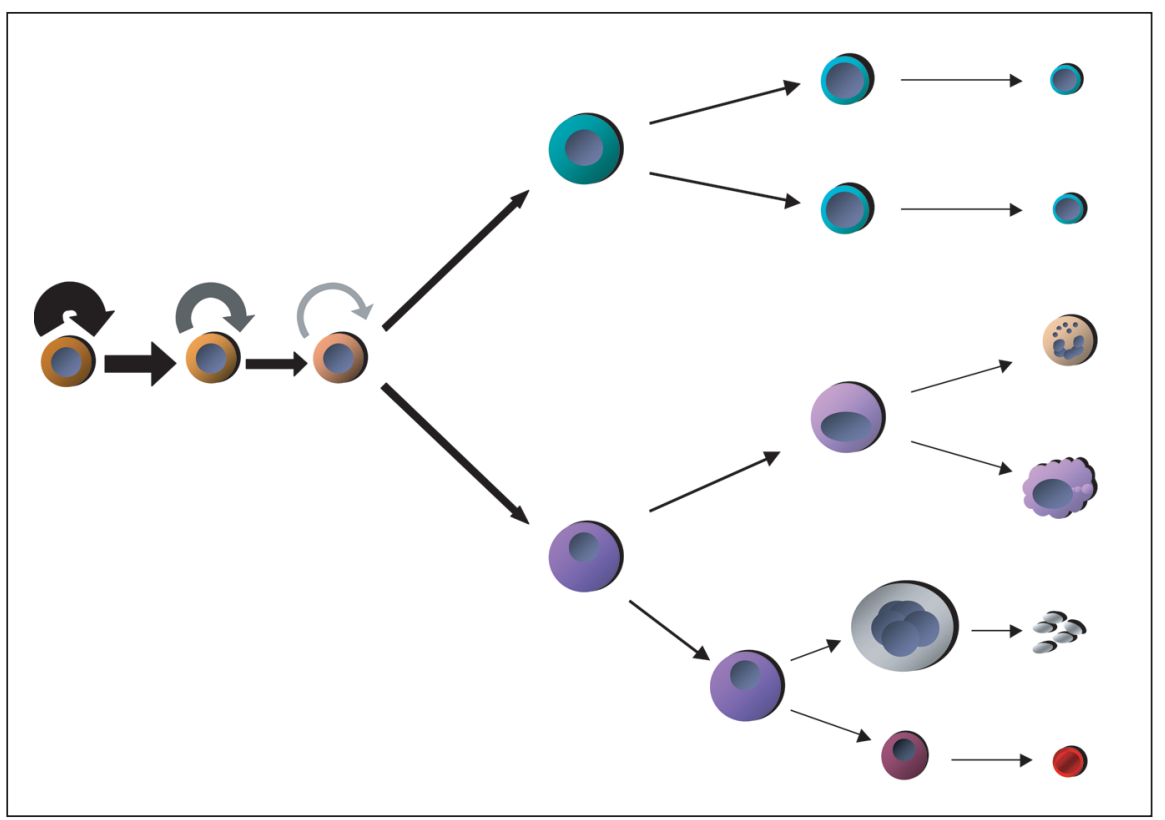

Figure 1. Simplified scheme of hematopoietic differentiation. The figure depicts the generally accepted hierarchical model of hematopoiesis, with unique stem cells giving rise in an orderly fashion to all the elements of the hematopoietic system. The curved arrows represent self-renewal potential, and the straight arrows represent proliferation ability. techniques that are currently being applied to understand how adult stem cells accomplish their role.

\section{TECHNIQUES TO IDENTIFY AND ISOLATE STEM CELLS}

\section{Sedimentation}

As soon as the existence of stem cells in the bone marrow was established, researchers started trying different approaches to isolate the fraction of bone marrow cells that contained the stem cell activity (Table 1). A few years after publishing their seminal paper on the colony forming units in the spleen (CFU-S) assay, Till and McCulloch (5) were able to fractionate whole bone marrow, using gravity and a discontinuous albumin gradient, into populations with different colony forming capacities and distinct abilities to selfrenew. Methods based on sedimenta- 
tion velocity differences among populations are still used as a first step to purify subsets of bone marrow, most notably a combination of a discontinuous gradient with a red blood cell aggregating agent, like Ficoll-Paque ${ }^{\mathrm{TM}}$ and Percoll $^{\mathrm{TM}}$ (Amersham Biosciences, Uppsala, Sweden) (7). A refinement of these strategies, centrifugal elutriation or counterflow centrifugation (8), has also had a prominent role in the field. This method was used in 1990 (9) to isolate four different fractions of mouse bone marrow that behaved very differently after transplantation into irradiated mice, demonstrating that cells responsible for short-term radiation protection and those involved in longerterm repopulation of bone marrow are physically distinct. More recently, a modification of this method (10) was used to isolate a bone marrow population that was used in single cell transplants, after selecting for cells that had homed to the bone marrow but had not divided immediately. These single cells appeared to be able not only to generate hematopoietic progeny but also to differentiate into other tissues (11).

\section{Fluorophore Efflux}

The advent of flow cytometry (12) allowed a closer look at a large number of individual cells from complex populations. Its first application to the field of stem cell biology explored the use of cytochemical techniques that were known to highlight particular cellular elements. This was the case of the vital fluorescent dyes Hoechst 33342 (bisbenzimide) and rhodamine 123 (13), which, among other potential advantages, are much cheaper than monoclonal antibodies.

Bisbenzimide derivatives were known to bind dsDNA preferentially in AT-rich regions proportionally to the cell ploidy, which explains why they were initially used in studies of the cell cycle. The first attempts to isolate stem cell populations from bone marrow based on Hoechst 33342 $(14,15)$ were able to identify heterogeneous hematopoietic fractions (comprising $6 \%$ and $0.23 \%$, respectively, of the whole bone marrow) enriched for stem cell activity by in vitro and in vivo assays. The stem cell fractions exhibited lower levels of fluorescence than the rest of the bone marrow. The authors suggested that stem cells could be less permeable to the dye, the dye had less accessibility to the DNA because the latter was more condensed or protein bound, or other cellular components with affinity to the dye were less abundant in these cells (15).

Later, it was fortuitously discovered that by simultaneously displaying the emission of the traditional wavelength (blue) and a higher one (red), distinct subpopulations could be resolved in whole bone marrow $(16,17)$ (Figure 2). In theory, the blue and the red light emission intensities should be proportional, and therefore the cells should align themselves in a straight profile. However, for a not entirely understood reason, different cell populations in the bone marrow display different spectral shift properties that confer diverse emission profiles. More importantly, a small proportion $(0.03 \%-0.07 \%)$ of bone marrow cells, which appear less fluorescent than the rest of the bone marrow, stand out as a distinct tail that was designated side population (SP). Phenotypic analysis has shown that the majority of the SP cells possess markers that have been know to be associated with stem cells, and transplant studies demonstrated that this population is highly enriched for stem cell activity. A similar population has been detected in other organs (18-20).

If bone marrow cells are simultaneously incubated with Hoechst and multidrug resistance protein (MDR) inhibitors such as verapamil, then the side population vanishes. This led to the idea that ATP binding cassette (ABC) transporters, a family of proteins that include MDR and were known to be present in HSCs (21), could be responsible for extruding the dye from the cells that make up the SP, causing them to appear less stained. Initial work showed that overexpression of MDR (ABCB1) seemed to increase the size of the SP (22), albeit causing a myeloproliferative disorder in animals transplanted with those cells (23), but the MDR knockout animals have a normal number of SP cells (24). Other candidate transporters such as breast cancer-related protein (ABCG2) have been proposed based on overex- pression (25-27) and knockout $(26,27)$ data, but it appears that, although ABCG2 may be sufficient to reveal the SP phenotype under the usual isolation procedure, it has not been proven necessary for the phenomenon to occur.

Rhodamine 123 has also been used alone $(28,29)$ and in combination with Hoechst 33342 (30) to define different bone marrow subsets; the fraction that contains greater stem cell activity also displays lower levels of staining by the dye (31). Rhodamine 123 appears to have selective affinity for mitochondria (32), and the first explanation that was put forward for the low staining of HSCs was that because these were thought to be metabolically quiescent unless they were required to divide, they should have a lower mitochondrial content compared to the rest of the bone marrow (28). However, the true explanation for this phenomenon is likely to be the same as that described for Hoechst because rhodamine is also known to be a substrate for some ABC transporters. One advantage of using rhodamine instead of Hoechst is that the former is less toxic for cells than the latter.

\section{Plating}

Another physical property that has been used to fractionate complex cell mixtures into subsets with distinct stem cell potential is the differential ability of cells to adhere to culture glass or plastic ware. This technique has found its main applications on the isolation of a primarily non-hematopoietic fraction of bone marrow and a mononuclear

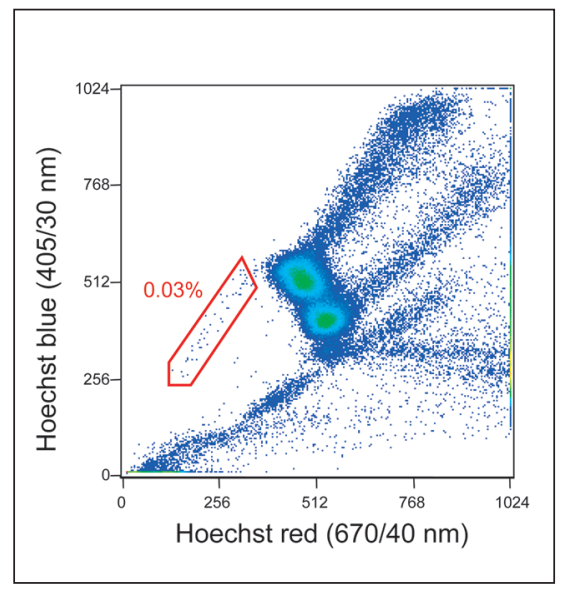

Figure 2. SP of murine bone marrow. 
fraction of muscle tissue that contains myogenic precursors.

Mesenchymal stem cells. The first reports of long-term bone marrow cultures date from the 1910s. In those and later works, it was observed that monolayer cultures of hematopoietic cells undergo a series of specific changes (33-36). In the first phase, non-adherent myeloid cells are morphologically distinguishable, with observable mitotic activity, but with a continuous decline in their numbers. This is followed by a period in which large, round monocytoid cells become attached to the substrate and, finally, by a stage characterized by the appearance of spindle-shaped cells that cover the culture fields and can be propagated indefinitely. These adherent cells, thought to correspond to the bone marrow stroma (i.e., non-hematopoietic elements), resemble fibroblasts in culture and at least some of them are able to form "fibroblastic colonies." However, the true nature of these cells was unknown until it was demonstrated that they possessed properties in common with fibroblasts from other tissues, other than just their morphology (37), even though fibroblastic markers present in other tissues were not found in these stromal cells (38).

During the second half of the last century, several in vitro and in vivo experiments showed that these bone marrow stromal cells have the ability to differentiate into several connective tissues, including cartilage, bone, adipose tissue (39-46), and myogenic cells (47). Because of the ability of these cells to give rise to different tissues, they have also been referred to as mesenchymal stem cells.

The plating procedure has recently been applied to isolate a population of bone marrow cells, after depletion for hematopoietic nucleated elements and erythrocytes. The cells thus obtained were called multipotential adult progenitor cells (MAPCs). This population has been shown to be able to differentiate in vitro and in transplant assays into endodermal, neuroectodermal, and other mesodermal derivatives, such as endothelium and muscle $(48,49)$. The exact biological meaning of this type of phenomenon is currently unknown because many of the conditions used in these experiments are non-physiological. In any case, if it remains practical to generate different types of tissues using these techniques, these findings will be quite fruitful.

Myogenic stem cells. A variation of these methods has been used in an attempt to purify myogenic stem cells. The feasibility of establishing primary muscle cell cultures was demonstrated using chick embryos in the early 1960 s $(50,51)$. Later that decade, another group described a method for purging non-myogenic cells from rat skeletal muscle cultures, based on the dissociation of cells and pre-plating $(52,53)$. Similar techniques have been applied to human (54) and murine (55) skeletal muscle to generate cells that can be shown to form myotubes in culture and to fuse with muscular fibers after in vivo transplantation. Even though the populations thus isolated are not homogeneous, it was believed that the mononuclear cells responsible for these findings were satellite cells, morphologically identified between the basement membrane and the myocytes. Further variation in derivation, notably the isolation of the slowest adhering fraction, has been used to distinguish a primitive or undifferentiated musclederived cell, called muscle-derived stem cells (MDSCs) (56), which are purported to generate non-muscular tissues (endothelium, peripheral nerve cells, and bone) (57).

Other tissue-specific stem cells. The combination of mechanical and enzymatic dissociation, culture, and selection of cells based on physical properties (e.g., morphology or aggregation) or immunocytochemistry has been used to define cell populations that are enriched for other organ-specific precursor cells. Examples include the nervous system (58-61), epidermis (62, $63)$, mammary gland (20), liver (64$66)$, pancreas (67-70), and gut $(71,72)$.

\section{Wheat Germ Agglutinin}

Another attempt to improve the homogeneity of populations containing stem cells isolated from bone marrow was the use of wheat germ agglutinin (WGA), which binds lectins, conjugated to a fluorophore. This method was combined with centrifugal elutriation 
(8), Hoechst staining (73), and surface markers (74), enabling the isolation of subpopulations that were enriched for stem cells according to in vivo assays.

\section{Cell-Surface Markers}

Although the early attempts to purify HSC utilizing physical properties led to the enrichment of cells responsible for establishing myeloid or erythroid lineages, the levels achieved were far below those expected for a homogeneous population of pluripotent HSCs $(75,76)$. The combination of FACS ${ }^{\circledR}$ with technologies for monoclonal antibody production (77) contributed to the next level of stem cell isolation. Cells could then be separated based on monoclonal antibody binding to cell-surface antigens either present or absent in a particular population or lineage. Antigen-specific antibodies are directly or indirectly conjugated to distinct fluorochromes that can be simultaneously detected in a FACS machine. Advanced cell sorters are able to routinely measure more than seven concurrent parameters, perform high-speed cell separation (approximately 30000 cells/s), and sort to extremely high purities. As is often the case in cell biology, the knowledge of the role of each marker in the cell lags behind the identification of the antigenic determinant.

The first monoclonal antibody used for the enrichment of HSC was the T cell associated antigen, Thy-1. This resulted in a 150 -fold enrichment for CFU-S in rat (78). Differentiated cells were later depleted by staining with a cocktail of antibodies against hematopoietic lineage antigens characteristic of lymphocytes, macrophages, granulocytes, or erythroblasts. This socalled Lin depletion is commonly used and results in a 10- to 20-fold enrichment for progenitors alone (79). The addition of an antibody against the Ly$6 \mathrm{~A} / \mathrm{E}$ mouse antigen, also known as stem cell antigen-1 (Sca-1), was able to further purify a murine Thy-1 low Lin ${ }^{\text {negSca-1pos }}$ (TLS) cell subset comprising approximately $0.07 \%$ of all marrow cells, resulting in a 1000 -fold enrichment (80). Antibodies against the tyrosine kinase receptor $c$-kit are now also used; the Lin $^{\text {negSca- }}$ pos $^{\text {c- }}$ Kitpos (KLS) population typically rep- resents approximately $0.1 \%$ of the nucleated cell population in the bone marrow and contains the entire hematopoietic activity in the mouse bone marrow as demonstrated by in vitro and in vivo assays $(81,82)$.

Further characterization of these highly enriched cell populations has revealed the existence of two functionally distinct HSC populations. Using single cell transplantation, it has been shown that the expression of the cellsurface glycoprotein CD34 subdivided the KLS compartment into a KLS CD34pos, containing the short-term progenitors, and a KLS CD34neg/low fraction, containing the long-term stem cells (83). Similarly, the KLS population can be sub-fractionated on the basis of the expression of the tyrosine kinase receptor Flk-2/Flt-3 (84). Upon transplantation, KLS Flk-2pos cells were only able to reconstitute cells of the lymphoid lineage, while the Flk$2^{\text {neg }}$ cells were capable of reconstituting all the hematopoietic lineages of the recipient mice. Together, these studies and others have allowed the definition of a general phenotype for the mouse long-term HSC (LT-HSC) that can be used to isolate these cells to apparent functional homogeneity.

Recently, similar strategies have been used to identify the transit progenitors committed to specific lineages. A common lymphoid progenitor (CLP) with the Lin ${ }^{\text {negSca-1 }}$ low $_{c-k i t l o w}$ Thy1 negIL-7Rpos phenotype has been isolated (85). Upon the transplantation of limiting cell numbers, it was shown that only cells of the lymphoid lineage (T, B, and NK cells) were rapidly generated. Similarly, a small subset of cells with the Lin ${ }^{\text {negSca-1 }}{ }^{\text {neg }}$ c-Kitpos CD34pos Fc $\gamma R^{\text {low }}$ surface phenotype has been identified and purified (85), which gave rise strictly to myeloid lineages (granulocytes, macrophages, megakaryocytes, and erythrocytes), having been denominated the common myeloid progenitor (CMP).

In conclusion, flow cytometric cell sorting in conjunction with in vivo assays has allowed for the definition of the hierarchy of hematopoietic progenitors that represent the critical developmental points at which fates seem to be decided. We believe that the use of similar approaches to study stem cell biol- ogy in non-hematopoietic tissues also has great potential, such as exemplified in studies of epidermal $(86,87)$, neural $(60,88)$, liver $(89)$, and mammary gland (20) stem cells.

\section{Molecular Genetics}

The application of more sophisticated molecular biology techniques has led to inventive new ways to isolate stem cells. One of these ways exploits the fact that certain genes appear to be exclusively expressed during the early phases of embryonic development in a tissue-specific fashion $(90,91)$. By placing a reporter gene under the control of a promoter that usually directs the activity of those early embryonic genes, one should be able to detect (e.g., with flow cytometry) the cells in which those genes are active, that is, the tissue-specific progenitor cells. This was done for cells expressing nestin and musashil or stem cell leukemia (SCL), and the authors were able to isolate cells that behaved as neural or hematopoietic progenitors with self-renewal and multilineage differentiation potential. The fundamental advantage of using this technique is that one only needs to know one gene that is expressed at a particular stage of differentiation to be able to isolate the cells of interest, which can then be further examined in detail. Furthermore, this approach can be used to purify stem cells from human tissues in which few markers may be known other than putative genes active in their murine counterparts.

\section{TECHNIQUES TO ASSAY DIFFERENTIATION AND SELF-RENEWAL POTENTIAL}

\section{In Vitro Assays}

In parallel with techniques to isolate stem cells, assays to measure stem cell potential both in vitro and in vivo have been developed (Table 2) (92-94). While the gold standard of any biological study is to show its importance in vivo, in vitro assays have been an invaluable starting point.

The basic premise behind in vitro culture assays is to recapitulate the con- 
Table 2. In Vitro and In Vivo Assays to Study Hematopoietic Progenitors and Stem Cells

\begin{tabular}{|c|c|c|c|c|}
\hline Assay & Type of Cell Detected & Stimulation & Readout & Time of Assay \\
\hline \multicolumn{5}{|l|}{ In Vitro } \\
\hline HPP-CFC & Progenitor & $\begin{array}{l}\text { CSF-1, G-CSF, GM-CSF, } \\
\text { IL-1 } 1 \alpha, \text { IL-3, SCF, bFGF }\end{array}$ & $\begin{array}{l}\text { Proliferative potential } \\
\left(>0.5 \mathrm{~mm} ;>5 \times 10^{4}\right. \\
\text { cells/colony) }\end{array}$ & $\begin{array}{l}\text { Approximately } \\
\text { two weeks }\end{array}$ \\
\hline CFU-C & Myeloid progenitor & SCF, GM-CSF, IL-3, EPO & $\begin{array}{l}\text { Number and type of } \\
\text { colonies }\end{array}$ & $\begin{array}{l}\text { Approximately } \\
\text { two weeks }\end{array}$ \\
\hline CFU-E & Erythroid progenitor & As for CFU-C & $\begin{array}{l}\text { Erythroid (small } \\
\text { hemoglobinized colonies) }\end{array}$ & 10-12 days \\
\hline BFU-E & $\begin{array}{l}\text { Primitive erythroid } \\
\text { progenitor }\end{array}$ & As for CFU-C & $\begin{array}{l}\text { Erythroid (large } \\
\text { hemoglobinized colonies) }\end{array}$ & $10-12,18$ days \\
\hline CFU-GM & $\begin{array}{l}\text { Granulocytic and } \\
\text { monocytic progenitors }\end{array}$ & As for CFU-C & $\begin{array}{l}\text { Large colonies with } \\
\text { granulocytes and } \\
\text { macrophages }\end{array}$ & $16-18$ days \\
\hline CFU-GEMM & $\begin{array}{l}\text { Most primitive myeloid } \\
\text { progenitor }\end{array}$ & As for CFU-C & $\begin{array}{l}\text { Large colonies with all } \\
\text { three cell types above }\end{array}$ & 16-18 days \\
\hline CAFC & Primitive progenitor & $\begin{array}{l}\text { irradiated adherent bone } \\
\text { marrow feeder layer }\end{array}$ & $\begin{array}{l}\text { Time of appearance } \\
\text { of colonies }\end{array}$ & a month \\
\hline LTC-IC & $\begin{array}{l}\text { primitive progenitor } \\
\text { and HSC? }\end{array}$ & $\begin{array}{l}\text { irradiated adherent bone } \\
\text { marrow feeder layer with } \\
\text { IL-3, IL-6, SCF-containing } \\
\text { media; followed by CFU-C } \\
\text { assay }\end{array}$ & $\begin{array}{l}\text { Ability to detect CFU } \\
\text { colonies after long period } \\
\text { in culture; length of time in } \\
\text { culture determines } \\
\text { primitiveness of cell type }\end{array}$ & $35-60$ days \\
\hline ELTC-IC & $\begin{array}{l}\text { Primitive progenitor, } \\
\text { and HSC? }\end{array}$ & As for LTC-IC & As for LTC-IC & $60-100$ days \\
\hline \multicolumn{5}{|l|}{ In Vivo } \\
\hline CFU-S & Progenitors and HSC & NA & $\begin{array}{l}\text { Macroscopic colonies } \\
\text { on spleen }\end{array}$ & 12 days \\
\hline Radioprotection & Progenitors and HSC & NA & Survival of irradiated host & 30 days \\
\hline $\begin{array}{l}\text { Competitive } \\
\text { transplant }\end{array}$ & Long-term HSC & NA & $\begin{array}{l}\text { Donor-derived multilineage } \\
\text { hematopoiesis }\end{array}$ & $16-52$ weeks \\
\hline $\begin{array}{l}\text { W mouse } \\
\text { transplant }\end{array}$ & Long-term HSC & NA & $\begin{array}{l}\text { Donor-derived multilineage } \\
\text { hematopoiesis }\end{array}$ & $16-52$ weeks \\
\hline \multicolumn{5}{|c|}{$\begin{array}{l}\text { CFU-E, colony forming units-erythroid; BFU-E, burst forming unit-erythroid; CFU-GM, colony forming units- } \\
\text { granulocyte/macrophage; CFU-GEMM, colony forming units granulocyte/erythroid/macrophage/megakaryocyte; LTC-IC, } \\
\text { long-term culture-initiating cells; ELTC-IC, enhanced long-term culture-initiating cells; W, white mutation- a series of mutants } \\
\text { harboring mutations in the c-Kit tyrosine kinase gene; CSF, colony stimulating factor; G-CSF, granulocyte-colony stimulating } \\
\text { factor; GM-CSF, granulocyte/macrophage-colony stimulating factor; IL, interleukin; SCF, stem cell factor; bFGF, basic fibrob- } \\
\text { last growth factor; EPO, erythropoietin. }\end{array}$} \\
\hline
\end{tabular}

ditions in vivo within more malleable and defined environments. The design of these assays is based on four basic assumptions about how primitive progenitors should behave in culture compared to more differentiated cells: $(i)$ colonies derived from primitive progenitors will arise later during culturing; (ii) the size of these colonies will be larger due to the greater proliferative potential; (iii) they will contain more types of differentiated cells; and (iv) will have a greater cytokine requirement. Convention holds that cell populations identified by a particular assay are referred to by that assay name. Several commonly used assays are described below.

High proliferative potential colony forming cells. In this assay, the proliferative potential of a cell population of hematopoietic cells cultured in the presence of various cytokines is compared. High proliferative potential-colony forming cells (HPP-CFC) are considered the most primitive cells because they give rise to large, latearising colonies.

Colony forming unit in culture. Colony forming unit in culture (CFU- 
C) protocols identify progenitor cells by measuring their ability to differentiate into multiple lineages. Several variations assess specific myeloid and erythroid progenitors (95-97). The cells are grown on methylcellulose, a semisolid media, containing different cytokines that induce differentiation down particular lineages. Progenitor capacity is measured by the number of colonies formed over a time course of two weeks and the cell types found within each colony. The cell types that are grown can be distinguished by their colony and cellular morphology, as well as by Wright-Giemsa staining.

Cobblestone-area forming cells. Cobblestone-area forming cells (CAFCs) are able to form colonies on a supportive irradiated stromal layer (98). Over the course of one month, hematopoietic colonies that appear on the feeder layer are categorized and quantified according to their appearance. Colonies located on the surface correspond to committed progenitors, while those forming cobblestone areas under the adherent layer are roughly equivalent to in vivo repopulating cells. The cobblestone areas arising at the end of the month show a time-dependent growth indicative of primitive cells. These late-forming colonies continue to give rise to the differentiated colonies found on the surface, illustrating a stem cell-like function.

Long-term colony-initiating cells and extended long-term colony-initiating cells. This method was described for studying human HSC, based on their ability to survive long periods in culture and subsequently differentiate. In the long-term colony-initiating cells (LTC-IC) and its variant, the extended long-term colony-initiating cells (ELTC-IC) assays (99-102), the test population is grown on a stromal feeder layer for 35-60 days. At several time points, aliquots are transferred to CFU$\mathrm{C}$ medium, where colonies of differentiated cells are scored (99). For ELTCIC, the original culture is carried out for 60-100 days, thus detecting an even more primitive population (101). Compared to other in vitro culture systems, LTC-IC and ELTC-IC are considered to be two of the more primitive cell types that can be measured in vitro but are still not as good a measure of stem cell potential as in vivo transplantation.

Other tissue stem cell in vitro methods. Although HSC assays are better established than other systems, in vitro assays exist for the study of other tissue stem cells such as muscle and the central nervous system. Neural stem cells can be propagated as neurospheres in epidermal growth factor or basic fibroblastic growth factor containing media. After plating in conditions where nutrients are limiting, differentiation into cells that have phenotypic properties of neurons and astrocytes occurs (103). Similar to the hematopoietic assays, the addition of different growth factors can lead to more astrocytes versus neurons or more dopaminergic versus serotinergic neurons $(104,105)$. Myogenic stem cells derived from skeletal muscle can also be propagated in vitro and then induced to differentiate with low-serum conditions (54).

\section{In Vivo Assays}

Although in vitro studies proved very useful for understanding the biology of the hematopoietic system, they fail to recapitulate all the events that occur in vivo. As already implied, the formation of a colony does not distinguish between a true stem cell and an already committed progenitor. Furthermore, apart from using specific cytokines, most in vitro systems use a cocktail of poorly defined factors such as those contained in serum. To avoid the limitations of the in vitro assays, several in vivo models that are mainly a variation of different transplantation strategies have been developed.

Progenitor assays: colonies in the spleen. In 1961, Till and McCulloch (5) described a method to measure the number of cells in a bone marrow suspension capable of continued proliferation, as assessed by the formation of hematopoietic colonies in the spleen, after the perfusion of fresh bone marrow into lethally irradiated recipients. This experiment established that normal bone marrow contains cells that are able to give rise to the different myeloid lineages. These CFU-S were shown to be clonal in origin and were estimated to be present at about 10 per $10^{5}$ nucleated bone marrow cells (106).
These cells were initially thought to be the ultimate hematopoietic stem cell, but years later it was revealed that this assay reflected the presence of committed progenitors, not stem cells $(75,81)$, and that the presence of CFU-S failed to predict long-term restoration of hematopoiesis (107).

Radioprotection. Another HSC assay is radioprotection, which is defined as the ability of a cell population to protect a host from a lethal dose of irradiation for at least 30 days. However, survival of the recipient mice does not necessarily require long-term hematopoietic function of the transplanted population. Total body irradiation spares some quiescent endogenous HSC, which, if given enough time to become activated, expand and produce mature cells; these radioresistant cells can thus reconstitute hematopoiesis in the absence of donor LT-HSC. In effect, the transplantation of highly purified progenitor populations can achieve 100 percent radioprotection but result in completely undetectable hematopoietic contribution 30 days after irradiation (108).

Long-term repopulation. The gold standard assay for true HSCs is longterm repopulation; that is, a test of the ability of the stem cell population to generate all hematopoietic progeny over a long period of time (four or more months). Two general strategies allow for the sensitive and quantitative determination of stem cell potential. The first assay, competitive transplantation, is based on the ability of an experimental population of hematopoietic cells to compete with a standard number of unmanipulated cells in the reconstitution of an irradiated recipient (109). The stem cell content of the experimental population is calculated relative to the normal competitor population. The second assay, which is less quantitative, uses a mouse strain in which the stem cells are constitutively absent. For repopulation with HSCs and neural crest and germ line stem cells, W mice that harbor mutations in the c-Kit tyrosine kinase receptor have been used to great advantage (110 112). Because wild-type stem cells have a growth advantage over those from the mutant animals, prior conditioning of the recipients is not required, 
and thus relatively small numbers of cells can be assayed.

In the murine system, repopulation assays have been facilitated by the availability of a plethora of strategies to distinguish donor-derived cells versus host-derived cells. Populations of cells from transgenic mice expressing reporter genes such as $\beta$-galactosidase or EGFP can be isolated and then transplanted into congenic recipients (113). These markers can be easily detected in a flow cytometric assay, thus providing a practical and clear-cut approach for tracking donor cells. Another widely used strategy to identify and quantitate donor cell types in the hematopoietic field has taken advantage of a natural polymorphism of a gene whose expression is restricted to the hematopoietic lineage. The cellsurface tyrosine phosphatase CD45 (also named leukocyte common antigen or Ly-5) is expressed in all nucleated hematopoietic cells. Two different variants of the CD45 gene product can be recognized by specific monoclonal antibodies and unequivocally distinguished by flow cytometry (114) or PCR (115). Furthermore, the availability of monoclonal antibodies to all the mature hematopoietic lineages permits a simultaneous analysis of the cell subtypes generated after the transplantation of the population of interest. The availability of congenic mice differing only at their CD45 locus allows for the detection and manipulation of up to three different cell types (homozygous CD45.1 and CD45.2 and heterozygous CD45.1 and CD45.2) in reconstitution experiments. We (16) and others (83) have used this system to demonstrate that individual physically isolated highly-purified HSC can give rise to all hematopoietic lineages in lethally irradiated recipients.

The hematopoietic system provides an optimal experimental system for transplantation assays. Key to this scheme is the ablation of the recipient's hematopoietic system so that transplanted donor cells have the "space" to seed empty stem cell niches and encounter a favorable environment to expand and to show their full differentiation potential. Genetic, surgical, chemical, or radiation strategies could be used to ablate the stem cell niche in other tissues. For example, a very useful experimental system has been developed for the study of hepatic progenitor populations (116) that utilizes mice genetically deficient for the fumarylacetoacetate hydrolase (FAH) enzyme. Hepatocytes lacking FAH expression accumulate toxic metabolic intermediates and eventually succumb in a cell autonomous fashion. Transplanted normal hepatocytes or candidate liver progenitor/stem cells have an ample survival advantage and eventually replace the vast majority of the liver parenchyma $(117,118)$. Several genetic models of non-hematopoietic stem cell deficiencies exist (119-121) that could be creatively utilized for customized stem cell-based assays.

Clonal analysis. Critical to studies of developmental potential and self-renewal capacity and central to the definition of a stem cell is the demonstration of these properties through clonal analysis. In other words, stem cells should be labeled as such only after showing that single cells can both selfrenew and give rise to populations of differentiated cells. In the following paragraphs, we discuss historical evidence and experimental techniques that have allowed the settlement of the concept of HSC as clonal developmental units.

Retroviral marking. A direct approach to study individual cells is to uniquely mark them before transplantation, which allows for the fate of the marked cells to be tracked in the recipient. Studies using the first unique markers, radiation-induced chromosomal translocations $(122,123)$, first demonstrated the existence of multipotential cells capable of long-term reconstitution. More recently, the proviral integration site of recombinant retroviruses (see the RNA-Based Vectors section of this review) has been used (124-126). Retroviral integration is largely random; thus, each transduced stem cell carries a distinct proviral integrant. Southern blotting or PCR can therefore be used to track the chromosomal DNA at the site of integration, which provides a unique tag for each transduced cell. The presence of the same proviral integrant in various cell lineages (e.g., T cells, B cells, and macrophages) proves that the initially 
marked cell had the developmental potential to differentiate at least along these lineages. A provirus that is detectable over a long period of time is also indicative of self-renewal; if each provirus was initially present in a single cell, then a clone capable of giving rise to a detectable signal over time indicates substantial proliferation. A more stringent measure of self-renewal requires the retransplantation of marked marrow, obtained from a primary reconstituted host, into multiple secondary recipients. The detection of a proviral integrant present in the primary host and in more than one secondary host serves as a direct demonstration of self-renewal.

Initial studies demonstrated that the different mature hematopoietic populations of the recipients contained the same viral integration site, which indicated that they originated from a common pluripotential cell and that relatively few stem cells are sufficient for hematopoiesis $(124,126)$. This observation, along with observations of dramatic fluctuations within the clonal make-up of the hematopoietic system of reconstituted mice, provided the initial support for the clonal succession model for hematopoiesis (127). This model proposed that stem cells had a limited life span, and therefore, at any given time, only a subset of the total population would be active (128). This permanent turnover in the active stem cell pool would lead to a change, over time, in the clonal make-up of the different hematopoietic lineages. However, later studies that extended the period of analysis up to 16 months showed that the formerly observed clonal fluctuation represented a hematopoietic system not yet functioning at equilibrium $(129,130)$. Early after transplantation, some clones contribute to all the lineages; however, 3-5 months after engraftment, these clones disappear, whereas other clones emerge and dominate hematopoiesis for the life span of the organism. This work supported the existence of pluripotent stem cells with a limited self-renewal capacity, now known as short-term HSC (ST-HSC) (129). Taken together, these findings did not support a clonal succession model of hematopoiesis, but rather indicated that, at least in lethally irradiated mice, the hematopoietic system is maintained by a small subset of longlived stem cells.

Single cell transplantation. Because few multipotent HSCs were required for hematopoiesis, a single, physically isolated LT-HSC should theoretically be able to engraft and productively contribute after transplantation into a conditioned recipient. If experimentally possible, this strategy could allow for the assessment of homogeneity and stem cell content in a prospectively identified stem cell population.

The first of such studies utilized a FACS-coupled single cell deposition device to accurately sort individual vi-

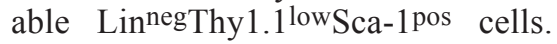
These were co-injected with 100 distinguishable, similarly purified stem cells to ensure the survival of the host. Of 280 animals transplanted with a single HSC, only two showed long-term multilineage reconstitution (131). In a more conclusive demonstration of robust and lifelong multilineage reconstitution by a single stem cell, other authors utilized single KLS CD34neg/low HSC in addition to $500 \mathrm{KLS}$ CD34pos cells as a means to provide short but not long-term reconstitution (83). Remarkably, they obtained successful engraftment in approximately $25 \%$ of the animals. Furthermore, long-term single cell-derived hematopoiesis reached levels of more than $80 \%$ in the peripheral blood of the majority of the recipients. When the bone marrow of these primary recipients was transplanted into secondary irradiated recipients, the authors found sustained multilineage reconstitution, which directly demonstrated self-renewal activity of a single LT-HSC.

\section{In Situ Analysis}

Stem cells are known to be quiescent but can be induced rapidly to cycle when stimulated. The administration of cytotoxic agents such as the nucleotide analog 5-fluorouracil (5-FU), which kills cycling cells, revealed bone marrow cells resistant to their effects (132, 133), demonstrating that long-term repopulating cells, quiescent at the time of drug administration, were capable of rapidly entering cell cycle (134).

Another nucleotide analog, bromod- eoxyuridine (BrdU), has been used to mark quiescent cells. BrdU becomes incorporated into replicating DNA and leads to DNA lesions after exposure to UV irradiation, but is benign otherwise. BrdU can be used to $(i)$ induce the death of cycling cells at any given time point after drug administration or (ii) label cells that retain BrdU due to their slow cycle time. The use of the first strategy allowed for the calculation of the turnover time of CFU-S and HPP-CFCs (135). The second strategy has been exploited in the hematopoietic system, skin, and mammary gland $(20,136$ 138). To track BrdU only in the rare, quiescent stem cells, it is administered continuously over several weeks, followed by a chase period to allow rapidly dividing cells to lose the BrdU. After this time, the tissue of interest is stained with an anti-BrdU antibody and examined for quiescent label-retaining cells.

Such studies applied to the bone marrow have shown that there is a small population of HSCs that cycle approximately every $30-60$ days $(136,139,140)$. In non-hematopoietic tissues, BrdU label retention has been used to localize hair follicle stem cells to the bulge area of the sebaceous glands and primitive mammary gland stem cells to the luminal epithelium of the mammary gland $(20,138)$. In situ analysis is important for the identification of stem cell architecture within a tissue, which is vital for fully understanding stem cell niches and the delicate interplay therein.

\section{Fate Mapping}

Transgenic mouse technology has been used to explore the origin and fate of HSCs in vivo. Transgenes that drive the expression of a reporter construct under a cell-type-specific reporter can be used to mark a cell type after it has passed a particular point in development. An example from the hematopoietic system is a mouse in which a complete Sca-1 promoter plus upstream regulatory elements drive lacZ expression (141). When Sca-1-lacZ embryos were examined, $\beta$-galactosidase staining was localized to the aorta-gonadmesonephros (AGM) region, corresponding to an area where definitive hematopoiesis is thought to arise. The 
restricted expression of the transgene in adult HSC and in embryonic tissues compared to extraembryonic tissues suggests that definitive hematopoiesis begins in the embryo.

A drawback with this single transgene marker is that transgene expression can be down-regulated over the course of development, and the marker is lost. The Cre-loxP system circumvents this problem (142). A cell-typespecific promoter drives Cre recombinase, and loxP sites flank a reporter gene inhibiting expression. After induction of the promotor, Cre recombinase is expressed, which leads to the loss of the loxP sites around the reporter, thus inducing irreversible reporter expression. Permanent transgene expression allows for the marking of cells even if transdifferentiation occurs $(143,144)$.

\section{TECHNIQUES FOR STUDYING HOW STEM CELLS WORK}

\section{Getting the Genes}

Subtractive libraries. In the past few years, several strategies have been used to elucidate the genetic program that underlies stem cell fate and function. The most common approach was to test candidate genes discovered in other systems for activity in HSCs. This generated some knowledge of HSC regulation, but there have been few candidate genes studied to date. More recently, groups have begun to view HSC gene expression from a more global perspective, profiling many transcripts from stem cells. The first attempt in HSC utilized subtractive library techniques (145), enriching the genes expressed in primitive cells by hybridizing or "subtracting out" common cDNAs with a driver population. Subtractive library strategies have been used in both mouse and human HSC studies (145-148). In one of these studies, more than 2000 genes were identified to be up-regulated in fetal liver HSC, which included known genes, expressed sequence tags, and completely novel genes.

Another study of HSC gene expression profile utilized cDNA subtraction in conjunction with microarray technology (147). The hallmark of this study was the construction of an HSCspecific gene chip using an HSC-enriched and lineage-depleted library. While the construction of such a microarray may be tedious, once it exists, multiple HSC progenitor and stem cell populations can be compared.

The advantage of subtractive libraries over other strategies such as microarrays is the ability to identify genes that are novel. While microarrays give information on a specific set of known targets, libraries enable the identification of any transcript that may be expressed in a given cell population.

SAGE. Another powerful approach that has been employed to gather information about the genetic expression profile of stem cells is the serial analysis of gene expression (SAGE) (149). In this technique, the mRNA molecules isolated from the population of cells being studied are initially anchored to a substrate by their poly(A) tails. After reverse transcription and second-strand synthesis, digestion with a specific restriction enzyme is performed, which leaves only a short $3^{\prime}$ end region attached to the substrate. The $3^{\prime}$ ends are then ligated to linkers that serve as recognition sites for a second restriction enzyme that cleaves the cDNA molecule from 10 to 14 nucleotides downstream. The short fragments originated are then concatenated, amplified by PCR, cloned, and sequenced. By comparing the short cloned sequences with a database, it is possible to define a genetic expression profile of the cells studied, although restricted to genes preexisting in the database. A refinement of this method (150) was used to study the pattern of gene expression in human CD34 positive cells (151).

Microarrays. The use of microarrays is currently revolutionizing all fields of biology, including stem cell genetics. This technology allows for the simultaneous detection of the expression of thousands of genes, starting with a small RNA sample. However, most of the highly enriched stem cell populations comprise a minimal number of cells, and the yield of RNA is still too low, which requires its amplification mediated by PCR or in vitro transcription (IVT). The PCR amplification relies on the addition of universal adapters to every cDNA molecule 
obtained after reverse transcription, which are then recognized by universal primers during PCR $(152,153)$. The IVT depends on the incorporation of a T7 RNA polymerase promoter during reverse transcription, and the promoter then directs the synthesis of RNA molecules that are the reverse complement of the original mRNA molecules (154). The products obtained can be labeled and incubated with the array. The amount of product that hybridizes to a particular spot in the array should be proportional to the gene expression level. The power of the microarray approach applied to stem cells was recently illustrated when these techniques were used to characterize the genetic expression profiles of different populations of stem cells to find genes that are common to all them $(155,156)$.

Single cell studies. Perhaps more important than the limitation in the number of cells obtained with the most stringent methods of stem cell isolation is the fact that whatever processes occur during stem cell differentiation, they are clonal; that is, at any stage, a specific group of progenitors could, in theory, be traced back to a single more primitive transit cell or to a unique stem cell. Therefore, the ability to study genetic expression at a single cell level would bear a tremendous impact on our understanding of the biology of this system. An appealing method is the global single cell RT-PCR (GSC RTPCR) $(157,158)$. In essence, the GSC RT-PCR amplifies preferentially the $3^{\prime}$ ends of every RNA molecule present in solution after the cell being studied is lysed. The cDNA molecules that are obtained can be used to construct a library or as targets for other techniques.

This method was used to study the fate of cells in culture along with the genetic expression profile of its sister cell, which are both derived from a single HSC. A correlation between the gene expression and the fate that the cells adopt- ed in culture was observed $(159,160)$ The reproducibility of this method seems to be adequate $(161,162)$, and the combination of this method with highthroughput technology could provide the answer to several interesting biological questions, including how homogeneous stem cell populations are and how cell commitment to differentiation is controlled.

\section{Knockouts}

The gold standard for studying a gene's function in vivo is to inactivate it and examine the ensuing phenotype, often with "knockout" (KO) technology (163). The first knockout that was examined that resulted in a HSC phenotype was for GATA-2, a basic helixloop-helix (bHLH) transcription factor involved in development (164). The GATA-2-/- animals were embryonic lethal, but the studies of early embryonic and yolk sac hematopoiesis showed 
that GATA-2 was important for early HSC function. Similarly, when SCL/ tal-1, a transcription factor previously known to be involved in angiogenesis, was knocked out, mice also died perinatally of severe anemia and almost complete absence of HSC, as deduced by the apparent absence of primitive or definitive hematopoiesis (165). Later studies of other transcription factors, such as Ikaros and Runx1, the cell-surface molecule c-mpl, and the gene for Sca-1 allowed for insight into adult HSC development (166-169). Mice null or possessing a DNA-binding-domain deletion for Ikaros have been made, illustrating that the protein-protein interaction domains of Ikaros have an important function that is separate from its DNA-binding domain.

More recently, powerful conditional knockouts using the Cre/lox system have been used. This system has allowed the demonstration of the requirement for vascular endothelium growth factor (VEGF) in HSC development (170) and its autocrine regulatory loop mechanism.

\section{Overexpression}

Gene transfer. A very practical approach for gain-of-function studies in stem cells is through genetic manipulation by viral-derived vectors. A variety of virus-based gene transfer systems have been engineered that allow for the efficient delivery of genes and regulatory elements in all kinds of mammalian cells (171). Because stem cells will undergo extensive proliferation to produce their multitude of progenitors and mature cells, the transferred gene must either stably integrate into the chromosomes or be maintained as a replicating episome capable of matching the rapid replication pace of the cells. Thus, integrating vectors such as retroviruses and adeno-associated viruses have been most extensively investigated for the genetic modification of stem cells.

RNA-based vectors. Retroviral vectors have the unique ability to integrate their genetic load into the host genome, therefore mediating stable modification of the target cells. Although integration does not guarantee stable expression of the transduced gene, it is an effective way to maintain genetic information in a self-renewing tissue. However, most retroviruses require cells in mitosis for productive infection (171). Because HSC are usually quiescent, the transduction efficiency of normal bone marrow HSC is limited. The stimulation of mitosis with 5FU or cytokines can lead to the proliferation of stem cells, therefore enhancing retroviral transduction efficiencies significantly $(172,173)$. Alternatively, transduced cells can be preselected before biological analysis. For example, the transduction of bone marrow cells with a retrovirus expressing the GFP reporter enables the selection of GFP-positive cells before transplantation (174).

Recently, vectors based on lentiviruses have been developed. These vectors offer an advantage over traditional retroviruses because they rely on the active transport of the pre-integration complex through the nuclear membrane by the import machinery of the target cell (171), enabling the infection of non-cycling cells such as HSC. Short ex vivo incubation with a lentiviral vector, with no need for cytokine stimulation, led to the efficient marking of human and primate HSC-originating long-term multilineage reconstitution in xenogeneic or autologous hosts (175-178). The potential of this new approach to improve gene transfer into HSC was dramatically demonstrated in a recent report describing the therapeutic correction of a mouse model of $\beta$ thalassamia (179).

The retroviral transduction of HSC has also led to the understanding of gene function by overexpression studies. The homeobox gene HoxB4 enhances the in vivo repopulating ability and significantly expands HSCs in culture $(180,181)$. Studies that overexpress genes such as the dominant-negative retinoic acid receptor (182), a constitutive form of the Notch receptor (183), and the MDR (184) have revealed functional roles for these gene products in HSC biology.

DNA-based vectors. Two DNAbased vectors have also been used for the transduction of HSC: adenoviral (Ad) and adeno-associated virus (AAV) vectors. Ad vectors can be produced in large quantities, transduce quiescent cells, and have been shown to efficiently transduce human and mouse HSCs without irreversibly changing the genome $(185,186)$. However, because Ad vectors are neither integrating nor self-replicating, they are unsuitable for the stable genetic modification of HSC. On the other hand, recombinant AAV integrate stably into cellular DNA and transduce both proliferating and nonproliferating cells. Reports on the usefulness of AAV for HSC transduction are controversial, with some investigators observing a high efficiency of infection (175) and others a low one (187). However, their utility for infecting other cell types has been repeatedly proven (188-190).

\section{FUTURE DIRECTIONS}

Here we have reviewed a wide variety of techniques that have been applied to the study of stem cells. Some of these methods (e.g., BrdU-label retention) have been utilized to study multiple stem cell types, while others have been under-exploited outside the hematopoietic system (e.g., flow cytometry for stem cell purification). With current attention turned to stem cells of all types, there is ample opportunity to apply lessons and techniques across disciplines to hopefully move us rapidly toward the numerous potential therapeutic applications of stem cells.

\section{ACKNOWLEDGMENTS}

We thank all the members of the Goodell laboratory for helpful discussions. M.A.G. is a Scholar of the Leukemia and Lymphoma Society. F.A.C. is a Fellow of the American Liver Foundation.

\section{REFERENCES}

1.Wulf, G.G., K.A. Jackson, and M.A. Goodell. 2001. Somatic stem cell plasticity: current evidence and emerging concepts. Exp. Hematol. 29:1361-1370

2.Lorenz, E., D. Uphoff, T.R. Reid, and E. Shelton. 1951. Modification of irradiation injury in mice and guinea pigs by bone marrow injections. J. Natl. Cancer Inst. 12:197-201.

3.Ford, C.E., J.L. Hamerton, D.W.H. Barnes, and J.F. Loutit. 1956. Cytological identification of radiation-chimaeras. Nature 177:452454. 
4.Nowell, P.C., L.J. Cole, J.G. Habermeyer, and P.L. Roan. 1956. Growth and continued function of rat marrow cells in X-radiated mice. Cancer Res. 16:258-261.

5.Till, J.E. and E.A. McCulloch. 1961. A direct measurement of the radiation sensitivity of normal mouse bone marrow cells. Radiat. Res. 14:213-222.

6.Potten, C.S. and M. Loeffler. 1990. Stem cells: attributes, cycles, spirals, pitfalls, and uncertainties. Lessons for and from the crypt. Development 110:1001-1020.

7.Boyum, A. 1968. Isolation of mononuclear cells and granulocytes from human blood. Isolation of monuclear cells by one centrifugation, and of granulocytes by combining centrifugation and sedimentation at $1 \mathrm{~g}$. Scand. J. Clin. Lab. Invest. Suppl. 97:77-89.

8.Ploemacher, R.E. and N.H. Brons. 1988. Isolation of hemopoietic stem cell subsets from murine bone marrow: I. Radioprotective ability of purified cell suspensions differing in the proportion of day-7 and day-12 CFU-S. Exp. Hematol. 16:21-26.

9.Jones, R.J., J.E. Wagner, P. Celano, M.S. Zicha, and S.J. Sharkis. 1990. Separation of pluripotent haematopoietic stem cells from spleen colony-forming cells. Nature 347:188189

10.Jones, R.J., M.I. Collector, J.P. Barber, M.S. Vala, M.J. Fackler, W.S. May, C.A. Griffin, A.L. Hawkins, et al. 1996. Characterization of mouse lymphohematopoietic stem cells lacking spleen colony-forming activity. Blood 88:487-491.

11.Krause, D.S., N.D. Theise, M.I. Collector, O. Henegariu, S. Hwang, R. Gardner, S. Neutzel, and S.J. Sharkis. 2001. Multi-organ, multi-lineage engraftment by a single bone marrow-derived stem cell. Cell 105:369377.

12.Hulett, H.R., W.A. Bonner, J. Barrett, and L.A. Herzenberg. 1969. Cell sorting: automated separation of mammalian cells as a function of intracellular fluorescence. Science 166:747-749.

13.Visser, J.W., S.J. Bol, and G. van den Engh. 1981. Characterization and enrichment of murine hemopoietic stem cells by fluorescence activated cell sorting. Exp. Hematol. 9:644655

14.Neben, S., W.J. Redfearn, M. Parra, G Brecher, and M.G. Pallavicini. 1991. Shortand long-term repopulation of lethally irradiated mice by bone marrow stem cells enriched on the basis of light scatter and Hoechst 33342 fluorescence. Exp. Hematol. 19:958967.

15.Baines, P. and J.W. Visser. 1983. Analysis and separation of murine bone marrow stem cells by $\mathrm{H} 33342$ fluorescence-activated cell sorting. Exp. Hematol. 11:701-708.

16.Goodell, M.A., K. Brose, G. Paradis, A.S. Conner, and R.C. Mulligan. 1996. Isolation and functional properties of murine hematopoietic stem cells that are replicating in vivo. J. Exp. Med. 183:1797-1806.

17.Goodell, M.A., M. Rosenzweig, H. Kim, D.F. Marks, M. DeMaria, G. Paradis, S.A. Grupp, C.A. Sieff, et al. 1997. Dye efflux studies suggest that hematopoietic stem cells expressing low or undetectable levels of
CD34 antigen exist in multiple species. Nat Med. 3:1337-1345.

18.McKinney-Freeman, S.L., K.A. Jackson, F.D. Camargo, G. Ferrari, F. Mavilio, and M.A. Goodell. 2002. Muscle-derived hematopoietic stem cells are hematopoietic in origin. Proc. Natl. Acad. Sci. USA 99:1341 1346.

19.Asakura, A. and M.A. Rudnicki. 2002. Side population cells from diverse adult tissues are capable of in vitro hematopoietic differentiation. Exp. Hematol. 30:1339-1345.

20.Welm, B.E., S.B. Tepera, T. Venezia, T.A. Graubert, J.M. Rosen, and M.A. Goodell. 2002. Sca-1(pos) cells in the mouse mammary gland represent an enriched progenitor cell population. Dev. Biol. 245:42-56.

21.Chaudhary, P.M. and I.B. Roninson. 1991. Expression and activity of P-glycoprotein, a multidrug efflux pump, in human hematopoietic stem cells. Cell 66:85-94.

22.Bunting, K.D., S. Zhou, T. Lu, and B.P. Sorrentino. 2000. Enforced P-glycoprotein pump function in murine bone marrow cells results in expansion of side population stem cells in vitro and repopulating cells in vivo. Blood 96:902-909.

23.Bunting, K.D., J. Galipeau, D. Topham, E. Benaim, and B.P. Sorrentino. 1999. Effects of retroviral-mediated MDR1 expression on hematopoietic stem cell self-renewal and differentiation in culture. Ann. NY Acad. Sci. 872:125-141.

24.Uchida, N., F. Leung, and C. Eaves. 2002 Liver and marrow of adult mdr- $1 \mathrm{a} / 1 \mathrm{~b}(-/-)$ mice show normal generation, function, and multi-tissue trafficking of primitive hematopoietic cells. Exp. Hematol. 30:862.

25.Scharenberg, C.W., M.A. Harkey, and B. Torok-Storb. 2002. The ABCG2 transporter is an efficient Hoechst 33342 efflux pump and is preferentially expressed by immature human hematopoietic progenitors. Blood 99: 507-512.

26.Zhou, S., J.D. Schuetz, K.D. Bunting, A.M. Colapietro, J. Sampath, J.J. Morris, I. Lagutina, G.C. Grosveld, et al. 2001. The $\mathrm{ABC}$ transporter Bcrp1/ABCG2 is expressed in a wide variety of stem cells and is a molecular determinant of the side-population phenotype. Nat. Med. 7:1028-1034.

27.Zhou, S., J.J. Morris, Y. Barnes, L. Lan, J.D. Schuetz, and B.P. Sorrentino. 2002 Bcrp1 gene expression is required for norma numbers of side population stem cells in mice, and confers relative protection to mitoxantrone in hematopoietic cells in vivo. Proc. Natl. Acad. Sci. USA 19:12339-12344.

28.Bertoncello, I., G.S. Hodgson, and T.R Bradley. 1985. Multiparameter analysis of transplantable hemopoietic stem cells: I. The separation and enrichment of stem cells homing to marrow and spleen on the basis of rhodamine-123 fluorescence. Exp. Hematol. 13: 999-1006.

29.Ploemacher, R.E. and R.H. Brons. 1989 Separation of CFU-S from primitive cells responsible for reconstitution of the bone marrow hemopoietic stem cell compartment following irradiation: evidence for a pre-CFU-S cell. Exp. Hematol. 17:263-266.

30.Wolf, N.S., A. Kone, G.V. Priestley, and 
S.H. Bartelmez. 1993. In vivo and in vitro characterization of long-term repopulating primitive hematopoietic cells isolated by sequential Hoechst 33342-rhodamine 123 FACS selection. Exp. Hematol. 21:614-622.

31.Li, C.L. and G.R. Johnson. 1992. Rhodamine123 reveals heterogeneity within murine Lin-, Sca-1+ hemopoietic stem cells. J. Exp. Med. 175:1443-1447.

32.Darzynkiewicz, Z., L. Staiano-Coico, and M.R. Melamed. 1981. Increased mitochondrial uptake of rhodamine 123 during lymphocyte stimulation. Proc. Natl. Acad. Sci. USA 78:2383-2387

33.Berman, L., S.C. S. and F.H. Ruddle. 1955. Long-term tissue culture of human bone marrow: I. Report of isolation of a strain of cells resembling epithelial cells from bone marrow of a patient with carcinoma of the lung. Blood 10:896-911.

34.McCulloch, E.A. and R.C. Parker. 1957. Continuous cultivation of cells of hemic origin. Canad. Cancer Conf. 2:152-167.

35.Berg, R.B. and M.S. Rosenthal. 1961. Studies of fibroblastic cells cultivated from bone marrow of leukemic and non-leukemic patients. Proc. Soc. Exp. Biol. 106:614-617.

36.Friedenstein, A.J., R.K. Chailakhjan, and K.S. Lalykina. 1970. The development of fibroblast colonies in monolayer cultures of guinea-pig bone marrow and spleen cells Cell Tissue Kinet. 3:393-403.

37.Castro-Malaspina, H., R.E. Gay, G. Resnick, N. Kapoor, P. Meyers, D. Chiarieri, S. McKenzie, H.E. Broxmeyer, et al. 1980. Characterization of human bone marrow fibroblast colony-forming cells (CFU-F) and their progeny. Blood 56:289-301.

38.Piersma, A.H., K.G. Brockbank, R.E. Ploemacher, E. van Vliet, K.M. Brakel-van Peer, and P.J. Visser. 1985. Characterization of fibroblastic stromal cells from murine bone marrow. Exp. Hematol. 13:237-243.

39.Friedenstein, A.J., R.K. Chailakhyan, and U.V. Gerasimov. 1987. Bone marrow osteogenic stem cells: in vitro cultivation and transplantation in diffusion chambers. Cell Tissue Kinet. 20:263-272.

40.Mardon, H.J., J. Bee, K. von der Mark, and M.E. Owen. 1987. Development of osteogenic tissue in diffusion chambers from early precursor cells in bone marrow of adult rats. Cell Tissue Res. 250:157-165.

41.Haynesworth, S.E., J. Goshima, V.M. Goldberg, and A.I. Caplan. 1992. Characterization of cells with osteogenic potential from human marrow. Bone 13:81-88.

42.Beresford, J.N., J.H. Bennett, C. Devlin, P.S. Leboy, and M.E. Owen. 1992. Evidence for an inverse relationship between the differentiation of adipocytic and osteogenic cells in rat marrow stromal cell cultures. J. Cell Sci. 102 (Pt 2):341-351.

43.Cheng, S.L., J.W. Yang, L. Rifas, S.F Zhang, and L.V. Avioli. 1994. Differentiation of human bone marrow osteogenic stromal cells in vitro: induction of the osteoblast phenotype by dexamethasone. Endocrinology 134:277-286.

44.Rickard, D.J., M. Kassem, T.E. Hefferan, G. Sarkar, T.C. Spelsberg, and B.L. Riggs. 1996. Isolation and characterization of os- teoblast precursor cells from human bone marrow. J. Bone Miner Res. 11:312-324.

45.Kuznetsov, S.A., P.H. Krebsbach, K. Satomura, J. Kerr, M. Riminucci, D. Benayahu, and P.G. Robey. 1997. Single-colony derived strains of human marrow stromal fibroblasts form bone after transplantation in vivo. J. Bone Miner Res. 12:1335-1347.

46.Pittenger, M.F., A.M. Mackay, S.C. Beck, R.K. Jaiswal, R. Douglas, J.D. Mosca, M.A. Moorman, D.W. Simonetti, S. Craig, et al. 1999. Multilineage potential of adult human mesenchymal stem cells. Science 284:143-147.

47.Wakitani, S., T. Saito, and A.I. Caplan. 1995. Myogenic cells derived from rat bone marrow mesenchymal stem cells exposed to 5-azacytidine. Muscle Nerve 18:1417-1426.

48.Reyes, M., T. Lund, T. Lenvik, D. Aguiar, L. Koodie, and C.M. Verfaillie. 2001. Purification and ex vivo expansion of postnatal human marrow mesodermal progenitor cells. Blood 98:2615-2625

49.Jiang, Y., B.N. Jahagirdar, R.L. Reinhardt, R.E. Schwartz, C.D. Keene, X.R. OrtizGonzalez, M. Reyes, T. Lenvik, et al. 2002. Pluripotency of mesenchymal stem cells derived from adult marrow. Nature 418:41-49.

50.Konigsberg, I.R. 1961. Cellular differentiation in colonies derived from single cell platings of freshly isolated chick embryo muscle cells. Proc. Natl. Acad. Sci. USA 47:18681872 .

51.Konigsberg, I.R. 1960. The differentiation of cross-striated myofibrils in short term cell culture. Exp. Cell Res. 21:414-420.

52.Yaffe, D. 1968. Retention of differentiation potentialities during prolonged cultivation of myogenic cells. Proc. Natl. Acad. Sci. USA 61:477-483.

53.Richler, C. and D. Yaffe. 1970. The in vitro cultivation and differentiation capacities of myogenic cell lines. Dev. Biol. 23:1-22.

54.Blau, H.M. and C. Webster. 1981. Isolation and characterization of human muscle cells. Proc. Natl. Acad. Sci. USA 78:5623-5627.

55.Rando, T.A. and H.M. Blau. 1994. Primary mouse myoblast purification, characterization, and transplantation for cell-mediated gene therapy. J. Cell Biol. 125:1275-1287.

56.Jankowski, R.J., B.M. Deasy, and J. Huard. 2002. Muscle-derived stem cells. Gene Ther. 9:642-647.

57.Qu-Petersen, Z., B. Deasy, R. Jankowski, M. Ikezawa, J. Cummins, R. Pruchnic, J. Mytinger, B. Cao, et al. 2002. Identification of a novel population of muscle stem cells in mice: potential for muscle regeneration. J. Cell Biol. 157:851-864.

58.Johansson, C.B., S. Momma, D.L. Clarke, M. Risling, U. Lendahl, and J. Frisen. 1999. Identification of a neural stem cell in the adult mammalian central nervous system. Cell 96: 25-34

59.Doetsch, F., I. Caille, D.A. Lim, J.M. Garcia-Verdugo, and A. Alvarez-Buylla. 1999. Subventricular zone astrocytes are neural stem cells in the adult mammalian brain. Cell 97:703-716

60.Morrison, S.J., P.M. White, C. Zock, and D.J. Anderson. 1999. Prospective identification, isolation by flow cytometry, and in vivo self-renewal of multipotent mammalian neur- al crest stem cells. Cell 96:737-749.

61.Temple, S. 2001. The development of neural stem cells. Nature 414:112-117.

62.Watt, F.M. 1998. Epidermal stem cells: markers, patterning and the control of stem cell fate. Philos. Trans. R. Soc. Lond. B Biol. Sci. 353:831-837.

63.Bianco, P. and P.G. Robey. 2001. Stem cells in tissue engineering. Nature 414:118-121.

64.Seglen, P.O. 1976. Preparation of isolated rat liver cells. Methods Cell Biol. 13:29-83.

65.Petersen, B.E. 2001. Hepatic "stem" cells: coming full circle. Blood Cells Mol. Dis. 27:590-600.

66.Alison, M.R., R. Poulsom, and S.J. Forbes. 2001. Update on hepatic stem cells. Liver 21:367-373.

67.Lacy, P.E. and M. Kostianovsky. 1967. Method for the isolation of intact islets of Langerhans from the rat pancreas. Diabetes 16:35-39.

68.Hunziker, E. and M. Stein. 2000. Nestin-expressing cells in the pancreatic islets of Langerhans. Biochem. Biophys. Res. Commun. 271:116-119.

69.Ramiya, V.K., M. Maraist, K.E. Arfors, D.A. Schatz, A.B. Peck, and J.G. Cornelius. 2000. Reversal of insulin-dependent diabetes using islets generated in vitro from pancreatic stem cells. Nat. Med. 6:278-282.

70.Serup, P. 2000. Panning for pancreatic stem cells. Nat. Genet. 25:134-135.

71.Potten, C.S. 1998. Stem cells in gastrointestinal epithelium: numbers, characteristics and death. Philos. Trans. R. Soc. Lond. B Biol Sci. 353:821-830

72.Clatworthy, J.P. and V. Subramanian 2001. Stem cells and the regulation of proliferation, differentiation and patterning in the intestinal epithelium: emerging insights from gene expression patterns, transgenic and gene ablation studies. Mech. Dev. 101:3-9.

73.McAlister, I., N.S. Wolf, M.E. Pietrzyk, P.S. Rabinovitch, G. Priestley, and B. Jaeger 1990. Transplantation of hematopoietic stem cells obtained by a combined dye method fractionation of murine bone marrow. Blood 75:1240-1246.

74.Jurecic, R., N.T. Van, and J.W. Belmont. 1993. Enrichment and functional characterization of Sca-1+WGA+, Lin-WGA+, LinSca-1+, and Lin-Sca-1+WGA+ bone marrow cells from mice with an Ly-6a haplotype. Blood 82:2673-2683.

75.Worton, R.G., E.A. McCulloch, and J.E. Till. 1969. Physical separation of hemopoietic stem cells differing in their capacity for selfrenewal. J. Exp. Med. 130:91-103.

76.van Bekkum, D.W., M.J. van Noord, B. Maat, and K.A. Dicke. 1971. Attempts at identification of hemopoietic stem cell in mouse. Blood 38:547-558.

77.Kohler, G. and C. Milstein. 1975. Continuous cultures of fused cells secreting antibody of predefined specificity. Nature 256:495-497.

78.Goldschneider, I., D. Metcalf, F. Battye, and T. Mandel. 1980. Analysis of rat hemopoietic cells on the fluorescence-activated cell sorter. I. Isolation of pluripotent hemopoietic stem cells and granulocyte-macrophage progenitor cells. J. Exp. Med. 152: 419-437. 
79.Muller-Sieburg, C.E., C.A. Whitlock, and I.L. Weissman. 1986. Isolation of two early B lymphocyte progenitors from mouse marrow: a committed pre-pre-B cell and a clonogenic Thy-1-lo hematopoietic stem cell. Cell 44:653-662.

80.Spangrude, G.J., S. Heimfeld, and I.L. Weissman. 1988. Purification and characterization of mouse hematopoietic stem cells. Science 241:58-62.

81.Okada, S., H. Nakauchi, K. Nagayoshi, S. Nishikawa, Y. Miura, and T. Suda. 1992 In vivo and in vitro stem cell function of ckit- and Sca-1-positive murine hematopoietic cells. Blood 80:3044-3050.

82.Morrison, S.J. and I.L. Weissman. 1994. The long-term repopulating subset of hematopoietic stem cells is deterministic and isolatable by phenotype. Immunity 1:661673

83. Osawa, M., K. Hanada, H. Hamada, and H. Nakauchi. 1996. Long-term lymphohematopoietic reconstitution by a single CD34-low/negative hematopoietic stem cell. Science 273:242-245.

84.Adolfsson, J., O.J. Borge, D. Bryder, K. Theilgaard-Monch, I. Astrand-Grundstrom, E. Sitnicka, Y. Sasaki, and S.E. Jacobsen. 2001. Upregulation of Flt3 expression within the bone marrow Lin(-)Sca1(+) c-kit(+) stem cell compartment is accompanied by loss of self-renewal capacity. Immunity 15:659-669.

85.Kondo, M., I.L. Weissman, and K. Akashi. 1997. Identification of clonogenic common lymphoid progenitors in mouse bone marrow. Cell 91:661-672.

86.Jones, P.H. and F.M. Watt. 1993. Separation of human epidermal stem cells from transit amplifying cells on the basis of differences in integrin function and expression. Cell 73:713-724.

87.Tani, H., R.J. Morris, and P. Kaur. 2000 Enrichment for murine keratinocyte stem cells based on cell surface phenotype. Proc. Natl. Acad. Sci. USA 97:10960-10965.

88.Uchida, N., D.W. Buck, D. He, M.J. Reitsma, M. Masek, T.V. Phan, A.S. Tsukamoto, F.H. Gage, et al. 2000. Direct isolation of human central nervous system stem cells. Proc. Natl. Acad. Sci. USA 97:14720-14725.

89.Suzuki, A., Y.W. Zheng, S. Kaneko, M Onodera, K. Fukao, H. Nakauchi, and H. Taniguchi. 2002. Clonal identification and characterization of self-renewing pluripotent stem cells in the developing liver. J. Cell Biol. 156:173-184.

90.Keyoung, H.M., N.S. Roy, A. Benraiss, A Louissaint, Jr., A. Suzuki, M. Hashimoto, W.K. Rashbaum, H. Okano, and S.A. Goldman. 2001. High-yield selection and extraction of two promoter-defined phenotypes of neural stem cells from the fetal human brain. Nat. Biotechnol. 19:843-850.

91.Chen, C.Z., M. Li, D. de Graaf, S. Monti, B. Gottgens, M.J. Sanchez, E.S. Lander, T.R. Golub, et al. 2002. Identification of endoglin as a functional marker that defines long-term repopulating hematopoietic stem cells. Proc. Natl. Acad. Sci. USA 99:1546815473

92.Bradley, T.R. and D. Metcalf. 1966. The growth of mouse bone marrow cells in vitro Aust. J. Exp. Biol. Med. Sci. 44:287-299.

93.Dicke, K.A., M.G. Platenburg, and D.W. van Bekkum. 1971. Colony formation in agar: in vitro assay for haemopoietic stem cells. Cell Tissue Kinet. 4:463-477.

94.Ichikawa, Y., D.H. Pluznik, and L. Sachs 1966. In vitro control of the development of macrophage and granulocyte colonies. Proc. Natl. Acad. Sci. USA 56:488-495.

95.Dexter, T.M., T.D. Allen, and L.G. Lajtha. 1977. Conditions controlling the proliferation of haemopoietic stem cells in vitro. J. Cell Physiol. 91:335-344.

96.Dexter, T.M., T.D. Allen, L.G. Lajtha, R. Schofield, and B.I. Lord. 1973. Stimulatio of differentiation and proliferation of haemopoietic cells in vitro. J. Cell Physiol. 82:461-473

97.Humphries, R.K., A.C. Eaves, and C.J. Eaves. 1979. Characterization of a primitive erythropoietic progenitor found in mouse marrow before and after several weeks in culture. Blood 53:746-763.

98.Ploemacher, R.E., J.P. van der Sluijs, J.S. Voerman, and N.H. Brons. 1989. An in vitro limiting-dilution assay of long-term repopulating hematopoietic stem cells in the mouse. Blood 74:2755-2763

99.Sutherland, H.J., C.J. Eaves, A.C. Eaves, W. Dragowska, and P.M. Lansdorp. 1989. Characterization and partial purification of human marrow cells capable of initiating long-term hematopoiesis in vitro. Blood 74:1563-1570

100.Sutherland, H.J., P.M. Lansdorp, D.H Henkelman, A.C. Eaves, and C.J. Eaves. 1990. Functional characterization of individ ual human hematopoietic stem cells cultured at limiting dilution on supportive marrow stromal layers. Proc. Natl. Acad. Sci. USA 87:3584-3588

101.Hao, Q.L., F.T. Thiemann, D. Petersen, E.M. Smogorzewska, and G.M. Crooks. 1996. Extended long-term culture reveals a highly quiescent and primitive human hematopoietic progenitor population. Blood 88:3306-3313.

102.Hao, Q.L., A.J. Shah, F.T. Thiemann, E.M. Smogorzewska, and G.M. Crooks. 1995. A functional comparison of CD34+ CD38- cells in cord blood and bone marrow. Blood 86:3745-3753.

103.Reynolds, B.A. and S. Weiss. 1992. Generation of neurons and astrocytes from isolated cells of the adult mammalian central nervous system. Science 255:1707-1710

104.Sanchez-Pernaute, R., L. Studer, K.S. Bankiewicz, E.O. Major, and R.D. McKay. 2001. In vitro generation and transplantation of precursor-derived human dopamine neurons. J. Neurosci. Res. 65:284-288.

105.Storch, A., G. Paul, M. Csete, B.O. Boehm, P.M. Carvey, A. Kupsch, and J. Schwarz 2001. Long-term proliferation and dopaminergic differentiation of human mesencephalic neural precursor cells. Exp. Neurol. 170:317-325.

106.Becker, A.J., E.A. McCulloch, and J.E. Till. 1963. Cytological demonstration of the clonal nature of spleen colonies derived from transplanted mouse marrow cells. $\mathrm{Na}$ - ture 197:452-454

107.Magli, M.C., N.N. Iscove, and N. Odartchenko. 1982. Transient nature of early haematopoietic spleen colonies. Nature 295:527-529.

108.Na Nakorn, T., D. Traver, I.L. Weissman, and K. Akashi. 2002. Myeloerythroid-restricted progenitors are sufficient to confer radioprotection and provide the majority of day 8 CFU-S. J. Clin. Invest. 109:15791585.

109.Harrison, D.E. 1980. Competitive repopulation: a new assay for long-term stem cell functional capacity. Blood 55:77-81.

110.Boggs, D.R., S.S. Boggs, D.F. Saxe, L.A. Gress, and D.R. Canfield. 1982 Hematopoietic stem cells with high proliferative potential. Assay of their concentration in marrow by the frequency and duration of cure of W/Wv mice. J. Clin. Invest. 70:242253.

111.Ogawa, T., I. Dobrinski, M.R. Avarbock, and R.L. Brinster. 2000. Transplantation of male germ line stem cells restores fertility in infertile mice. Nat. Med. 6:29-34.

112.Huszar, D., A. Sharpe, and R. Jaenisch. 1991. Migration and proliferation of cultured neural crest cells in W mutant neural crest chimeras. Development 112:131-141.

113.Zambrowicz, B.P., A. Imamoto, S. Fiering, L.A. Herzenberg, W.G. Kerr, and P. Soriano. 1997. Disruption of overlapping transcripts in the ROSA $\beta$-geo 26 gene trap strain leads to widespread expression of $\beta$ galactosidase in mouse embryos and hematopoietic cells. Proc. Natl. Acad. Sci. USA 94:3789-3794.

114.Shen, F.W., J.S. Tung, and E.A. Boyse. 1986. Further definition of the Ly-5 system. Immunogenetics 24:146-149.

115.Ramos, C.A., Y. Zheng, I. Colombowala, and M.A. Goodell. 2003. Tracing the origin of non-hematopoietic cells using CD45 PCR restriction fragment length polymorphisms. BioTechniques 34:160-162.

116.Overturf, K., M. Al-Dhalimy, R. Tanguay, M. Brantly, C.N. Ou, M. Finegold, and M. Grompe. 1996. Hepatocytes corrected by gene therapy are selected in vivo in a murine model of hereditary tyrosinaemia type I. Nat. Genet. 12:266-273.

117.Lagasse, E., H. Connors, M. Al-Dhalimy, M. Reitsma, M. Dohse, L. Osborne, X Wang, M. Finegold, et al. 2000. Purified hematopoietic stem cells can differentiate into hepatocytes in vivo. Nat. Med. 6:12291234.

118.Wang, X., M. Al-Dhalimy, E. Lagasse, M. Finegold, and M. Grompe. 2001. Liver repopulation and correction of metabolic liver disease by transplanted adult mouse pancreatic cells. Am. J. Pathol. 158:571-579.

119.Korinek, V., N. Barker, P. Moerer, E. van Donselaar, G. Huls, P.J. Peters, and $\mathbf{H}$ Clevers. 1998. Depletion of epithelial stemcell compartments in the small intestine of mice lacking Tcf-4. Nat. Genet. 19:379-383.

120.Seale, P., L.A. Sabourin, A. Girgis-Gabardo, A. Mansouri, P. Gruss, and M.A. Rudnicki. 2000. Pax7 is required for the specification of myogenic satellite cells. Cell 102: 777-786. 
121.Waikel, R.L., Y. Kawachi, P.A. Waikel, X.J. Wang, and D.R. Roop. 2001. Deregulated expression of c-Myc depletes epidermal stem cells. Nat. Genet. 28:165-168.

122.Wu, A.M., J.E. Till, L. Siminovitch, and E.A. McCulloch. 1968. Cytological evidence for a relationship between normal hemotopoietic colony-forming cells and cells of the lymphoid system. J. Exp. Med. 127: 455-464.

123.Abramson, S., R.G. Miller, and R.A. Phillips. 1977. The identification in adult bone marrow of pluripotent and restricted stem cells of the myeloid and lymphoid systems. J. Exp. Med. 145:1567-1579.

124.Keller, G., C. Paige, E. Gilboa, and E.F. Wagner. 1985. Expression of a foreign gene in myeloid and lymphoid cells derived from multipotent haematopoietic precursors. Nature 318:149-154.

125.Dick, J.E., M.C. Magli, D. Huszar, R.A. Phillips, and A. Bernstein. 1985. Introduction of a selectable gene into primitive stem cells capable of long-term reconstitution of the hemopoietic system of $\mathrm{W} / \mathrm{Wv}$ mice. Cell 42:71-79.

126.Lemischka, I.R., D.H. Raulet, and R.C. Mulligan. 1986. Developmental potential and dynamic behavior of hematopoietic stem cells. Cell 45:917-927.

127.Snodgrass, R. and G. Keller. 1987. Clonal fluctuation within the haematopoietic system of mice reconstituted with retrovirus-infected stem cells. EMBO J. 6:3955-3960.

128.Hellman, S., U. Reincke, L. Botnick, and P. Mauch. 1983. Functional organization of the hematopoietic stem cell compartment: implications for cancer and its therapy. J. Clin. Oncol. 1:277-284

129.Keller, G. and R. Snodgrass. 1990. Life span of multipotential hematopoietic stem cells in vivo. J. Exp. Med. 171:1407-1418

130.Jordan, C.T. and I.R. Lemischka. 1990 Clonal and systemic analysis of long-term hematopoiesis in the mouse. Genes Dev. 4:220-232.

131.Smith, L.G., I.L. Weissman, and S. Heimfeld. 1991. Clonal analysis of hematopoietic stem-cell differentiation in vivo. Proc. Natl. Acad. Sci. USA 88:2788-2792.

132.Hodgson, G.S. and T.R. Bradley. 1979. Properties of haematopoietic stem cells surviving 5-fluorouracil treatment: evidence for a pre-CFU-S cell? Nature 281:381-382.

133.Van Zant, G. 1984. Studies of hematopoietic stem cells spared by 5-fluorouracil. J Exp. Med. 159:679-690.

134.Lerner, C. and D.E. Harrison. 1990. 5-Fluorouracil spares hemopoietic stem cells responsible for long-term repopulation. Exp. Hematol. 18:114-118.

135.Hodgson, G.S. and T.R. Bradley. 1984. In vivo kinetic status of hematopoietic stem and progenitor cells as inferred from labeling with bromodeoxyuridine. Exp. Hematol. 12:683-687.

136.Bradford, G.B., B. Williams, R. Rossi, and I. Bertoncello. 1997. Quiescence, cycling, and turnover in the primitive hematopoietic stem cell compartment. Exp. Hematol. 25: 445-453.

137.Mackenzie, I.C. and J.R. Bickenbach.
1985. Label-retaining keratinocytes and Langerhans cells in mouse epithelia. Cell Tissue Res. 242:551-556.

138.Cotsarelis, G., T.T. Sun, and R.M. Lavker. 1990. Label-retaining cells reside in the bulge area of pilosebaceous unit: implications for follicular stem cells, hair cycle, and skin carcinogenesis. Cell 61:1329-1337.

139.Fleming, W.H., E.J. Alpern, N. Uchida, K. Ikuta, G.J. Spangrude, and I.L. Weissman. 1993. Functional heterogeneity is associated with the cell cycle status of murine hematopoietic stem cells. J. Cell Biol. 122:897-902.

140.Cheshier, S.H., S.J. Morrison, X. Liao, and I.L. Weissman. 1999. In vivo proliferation and cell cycle kinetics of long-term selfrenewing hematopoietic stem cells. Proc. Natl. Acad. Sci. USA 96:3120-3125.

141.Miles, C., M.J. Sanchez, A. Sinclair, and E. Dzierzak. 1997. Expression of the Ly6E.1 (Sca-1) transgene in adult hematopoietic stem cells and the developing mouse embryo. Development 124:537-547.

142.Zinyk, D.L., E.H. Mercer, E. Harris, D.J. Anderson, and A.L. Joyner. 1998. Fate mapping of the mouse midbrain-hindbrain constriction using a site-specific recombination system. Curr. Biol. 8:665-668.

143.Orban, P.C., D. Chui, and J.D. Marth. 1992. Tissue- and site-specific DNA recombination in transgenic mice. Proc. Natl. Acad. Sci. USA 89:6861-6865.

144.Herrera, P.L., L. Orci, and J.D. Vassalli. 1998. Two transgenic approaches to define the cell lineages in endocrine pancreas development. Mol. Cell Endocrinol. 140:4550.

145.Phillips, R.L., R.E. Ernst, B. Brunk, N. Ivanova, M.A. Mahan, J.K. Deanehan, K.A. Moore, G.C. Overton, and I.R. Lemischka. 2000. The genetic program of hematopoietic stem cells. Science 288:16351640

146.Zhang, Q.H., M. Ye, X.Y. Wu, S.X. Ren, M. Zhao, C.J. Zhao, G. Fu, Y. Shen, et al. 2000. Cloning and functional analysis of cDNAs with open reading frames for 300 previously undefined genes expressed in CD34+ hematopoietic stem/progenitor cells. Genome Res. 10:1546-1560

147.Park, I.K., Y. He, F. Lin, O.D. Laerum, Q. Tian, R. Bumgarner, C.A. Klug, K. Li, et al. 2002. Differential gene expression profiling of adult murine hematopoietic stem cells. Blood 99:488-498.

148. Terskikh, A.V., M.C. Easterday, L. Li, L. Hood, H.I. Kornblum, D.H. Geschwind, and I.L. Weissman. 2001. From hematopoiesis to neuropoiesis: evidence of overlapping genetic programs. Proc. Natl. Acad. Sci. USA 98:7934-7939.

149.Velculescu, V.E., L. Zhang, B. Vogelstein, and K.W. Kinzler. 1995. Serial analysis of gene expression. Science 270:484-487.

150.Lee, S., J. Chen, G. Zhou, and S.M. Wang. 2001. Generation of high-quantity and quality tag/ditag cDNAs for SAGE analysis. BioTechniques 31:348-354.

151.Zhou, G., J. Chen, S. Lee, T. Clark, J.D. Rowley, and S.M. Wang. 2001. The pattern of gene expression in human CD34(+) stem/ progenitor cells. Proc. Natl. Acad. Sci. USA 98:13966-13971

152.Belyavsky, A., T. Vinogradova, and K. Rajewsky. 1989. PCR-based cDNA library construction: general cDNA libraries at the level of a few cells. Nucleic Acids Res. 17:2919-2932 [erratum in Nucleic Acids Res. 1989. 291:5883].

153.Tam, A.W., M.M. Smith, K.E. Fry, and J.W. Larrick. 1989. Construction of cDNA libraries from small numbers of cells using sequence independent primers. Nucleic Acids Res. 17:1269.

154.Van Gelder, R.N., M.E. von Zastrow, A. Yool, W.C. Dement, J.D. Barchas, and J.H. Eberwine. 1990. Amplified RNA synthesized from limited quantities of heterogeneous cDNA. Proc. Natl. Acad. Sci. USA 87:1663-1667.

155.Ivanova, N.B., J.T. Dimos, C. Schaniel, J.A. Hackney, K.A. Moore, and I.R. Lemischka. 2002. A stem cell molecular signature. Science 298:601-604.

156.Ramalho-Santos, M., S. Yoon, Y. Matsuzaki, R.C. Mulligan, and D.A. Melton. 2002. "Stemness": transcriptional profiling of embryonic and adult stem cells. Science 298:597-600.

157.Brady, G., M. Barbara, and N. Iscove. 1990. Representative in vitro cDNA amplification from individual hemopoietic cells and colonies. Methods Mol. Cell. Biol. 2:17-25.

158.Brady, G. and N.N. Iscove. 1993. Construction of cDNA libraries from single cells. Methods Enzymol. 225:611-623.

159.Brady, G., F. Billia, J. Knox, T. Hoang, I.R. Kirsch, E.B. Voura, R.G. Hawley, R. Cumming, M. Buchwald, et al. 1995. Analysis of gene expression in a complex differentiation hierarchy by global amplification of cDNA from single cells. Curr. Biol. 5:909-922.

160.Billia, F., M. Barbara, J. McEwen, M. Trevisan, and N.N. Iscove. 2001. Resolution of pluripotential intermediates in murine hematopoietic differentiation by global complementary DNA amplification from single cells: confirmation of assignments by expression profiling of cytokine receptor transcripts. Blood 97:2257-2268.

161.Brail, L.H., A. Jang, F. Billia, N.N. Iscove, H.J. Klamut, and R.P. Hill. 1999. Gene expression in individual cells: analysis using global single cell reverse transcription polymerase chain reaction (GSC RT-PCR). Mutat. Res. 406:45-54.

162.Iscove, N.N., M. Barbara, M. Gu, M. Gibson, C. Modi, and N. Winegarden. 2002 Representation is faithfully preserved in global cDNA amplified exponentially from sub-picogram quantities of mRNA. Nat. Biotechnol. 20:940-943.

163.Sands, A., L.A. Donehower, and A. Bradley. 1994. Gene-targeting and the p53 tumorsuppressor gene. Mutat. Res. 307:557-572.

164.Tsai, F.Y., G. Keller, F.C. Kuo, M. Weiss, J. Chen, M. Rosenblatt, F.W. Alt, and S.H Orkin. 1994. An early haematopoietic defect in mice lacking the transcription factor GATA-2. Nature 371:221-226.

165.Shivdasani, R.A., E.L. Mayer, and S.H. Orkin. 1995. Absence of blood formation in 
mice lacking the T-cell leukaemia oncoprotein tal-1/SCL. Nature 373:432-434.

166.Solar, G.P., W.G. Kerr, F.C. Zeigler, D. Hess, C. Donahue, F.J. de Sauvage, and D.L. Eaton. 1998. Role of c-mpl in early hematopoiesis. Blood 92:4-10.

167.Nichogiannopoulou, A., M. Trevisan, S. Neben, C. Friedrich, and K. Georgopoulos. 1999. Defects in hemopoietic stem cell activity in Ikaros mutant mice. J. Exp. Med. 190:1201-1214.

168.North, T.E., M.F. de Bruijn, T. Stacy, L. Talebian, E. Lind, C. Robin, M. Binder, E. Dzierzak, and N.A. Speck. 2002. Runx1 expression marks long-term repopulating hematopoietic stem cells in the midgestation mouse embryo. Immunity 16:661-672.

169.Ito, C.Y., C.Y. Li, A. Bernstein, J.E. Dick, and W.L. Stanford. 2003. Hematopoietic stem cell and progenitor defects in Sca-1/Ly6A-null mice. Blood 101:517-523.

170.Gerber, H.P., A.K. Malik, G.P. Solar, D. Sherman, X.H. Liang, G. Meng, K. Hong, J.C. Marsters, et al. 2002. VEGF regulates haematopoietic stem cell survival by an internal autocrine loop mechanism. Nature 417:954-958

171.Kay, M.A., J.C. Glorioso, and L. Naldini. 2001. Viral vectors for gene therapy: the art of turning infectious agents into vehicles of therapeutics. Nat. Med. 7:33-40.

172.Cheng, L., C. Du, C. Lavau, S. Chen, J. Tong, B.P. Chen, R. Scollay, R.G. Hawley, and B. Hill. 1998. Sustained gene expression in retrovirally transduced, engrafting human hematopoietic stem cells and their lympho-myeloid progeny. Blood 92:83-92.

173.Miller, C.L. and C.J. Eaves. 1997. Expansion in vitro of adult murine hematopoietic stem cells with transplantable lymphomyeloid reconstituting ability. Proc. Natl. Acad. Sci. USA 94:13648-13653.

174.Pawliuk, R., T. Bachelot, R.J. Wise, M.M. Mathews-Roth, and P. Leboulch. 1999. Long-term cure of the photosensitivity of murine erythropoietic protoporphyria by preselective gene therapy. Nat. Med. 5:768773.

175.Chatterjee, S., W. Li, C.A. Wong, G. Fisher-Adams, D. Lu, M. Guha, J.A. Macer, S.J. Forman, et al. 1999. Transduction of primitive human marrow and cord blood-derived hematopoietic progenitor cells with adeno-associated virus vectors. Blood 93:1882-1894.

176.Guenechea, G., O.I. Gan, T. Inamitsu, C. Dorrell, D.S. Pereira, M. Kelly, L. Naldini, and J.E. Dick. 2000. Transduction of human CD34+CD38- bone marrow and cord blood-derived SCID-repopulating cells with third-generation lentiviral vectors. Mol. Ther. 1:566-573.

177.Miyoshi, H., K.A. Smith, D.E. Mosier, I.M. Verma, and B.E. Torbett. 1999 Transduction of human CD34+ cells that mediate long-term engraftment of NOD/ SCID mice by HIV vectors. Science 283:682-686

178. Tahara-Hanaoka, S., K. Sudo, H. Ema, H. Miyoshi, and H. Nakauchi. 2002. Lentiviral vector-mediated transduction of murine CD34(-) hematopoietic stem cells. Exp.
Hematol. 30:11-17.

179.May, C., S. Rivella, J. Callegari, G. Heller, K.M. Gaensler, L. Luzzatto, and M. Sadelain. 2000. Therapeutic haemoglobin synthesis in $\beta$-thalassaemic mice expressing lentivirus-encoded human $\beta$-globin. Nature 406:82-86.

180.Sauvageau, G., U. Thorsteinsdottir, C.J. Eaves, H.J. Lawrence, C. Largman, P.M Lansdorp, and R.K. Humphries. 1995 Overexpression of HOXB4 in hematopoietic cells causes the selective expansion of more primitive populations in vitro and in vivo. Genes Dev. 9:1753-1765.

181.Antonchuk, J., G. Sauvageau, and R.K. Humphries. 2002. HOXB4-induced expansion of adult hematopoietic stem cells ex vivo. Cell 109:39-45.

182.Tsai, S., S. Bartelmez, E. Sitnicka, and S. Collins. 1994. Lymphohematopoietic progenitors immortalized by a retroviral vecto harboring a dominant-negative retinoic acid receptor can recapitulate lymphoid, myeloid, and erythroid development. Genes Dev. 8:2831-2841.

183.Varnum-Finney, B., L. Xu, C. BrashemStein, C. Nourigat, D. Flowers, S. Bakkour, W.S. Pear, and I.D. Bernstein. 2000 Pluripotent, cytokine-dependent, hematopoietic stem cells are immortalized by constitutive Notch1 signaling. Nat. Med. 6:1278 1281

184.Bunting, K.D., J. Galipeau, D. Topham, E. Benaim, and B.P. Sorrentino. 1998. Transduction of murine bone marrow cells with an MDR1 vector enables ex vivo stem cell expansion, but these expanded grafts cause a myeloproliferative syndrome in transplanted mice. Blood 92:2269-2279.

185.Frey, B.M., N.R. Hackett, J.M. Bergelson, R. Finberg, R.G. Crystal, M.A. Moore, and S. Rafii. 1998. High-efficiency gene transfer into ex vivo expanded human hematopoietic progenitors and precursor cells by adenovirus vectors. Blood 91:2781 2792.

186.Bradfute, S. and M.A. Goodell. Adenoviral transduction of mouse hematopoietic stem cells. Mol. Ther. (In Press.)

187.Russell, D.W. and M.A. Kay. 1999. Adenoassociated virus vectors and hematology. Blood 94:864-874

188.Jung, S.C., I.P. Han, A. Limaye, R. Xu M.P. Gelderman, P. Zerfas, K. Tirumalai, G.J. Murray, et al. 2001. Adeno-associate viral vector-mediated gene transfer results in long-term enzymatic and functional correction in multiple organs of Fabry mice. Proc. Natl. Acad. Sci. USA 98:2676-2681.

189.Kaplitt, M.G., P. Leone, R.J. Samulski, X. Xiao, D.W. Pfaff, K.L. O'Malley, and M.J. During. 1994. Long-term gene expression and phenotypic correction using adeno-associated virus vectors in the mammalian brain. Nat. Genet. 8:148-154.

190.Kay, M.A., C.S. Manno, M.V. Ragni, P.J. Larson, L.B. Couto, A. McClelland, B. Glader, A.J. Chew, et al. 2000. Evidence for gene transfer and expression of factor IX in haemophilia B patients treated with an AAV vector. Nat. Genet. 24:257-261.
Address correspondence to:

Dr. Margaret A. Goodell

Center for Cell and Gene Therapy

Department of Pediatrics

Baylor College of Medicine

Houston, TX 77030, USA

e-mail: goodell@bcm.tmc.edu 